\title{
THE EFFECT OF INTRINSIC MOTIVATION AND COMMUNICATION ON EMPLOYEE CASHIER PERFORMANCE IN TRANSMART NGAGEL SURABAYA
}

\author{
Akhmad Rosidi ${ }^{1,}$ Bayu Airlangga Putra $^{2}$, Mochammad Arif $^{3}$ \\ akhmasrosidi07@gmail.com¹, bayu.airlangga@narotama.ac.id², muchamad.arif@narotama.ac.id ${ }^{3}$ \\ Narotama University, Faculty of Economics and Business, \\ Jl Arief Rachman Hakim 51, Sukolilo, Surabaya ${ }^{1,2}$
}

\begin{abstract}
.
his study aims to determine the relationship between intrinsic motivation and communication on improving the performance of cashier employees at Transmart Ngagel Surabaya. This research is quantitative research. With a population of 98 respondents. Data collection techniques using interviews, observation and questionnaires. Analysis of the data used is validity test, reliability test, classic assumption test and multiple linear analysis test. The results showed that the influence of intrinsic motivation and communication on the performance of the cashier employees at Transmart Ngagel Surabaya showed positive and significant results. The result of the $F$ test is $69,428>\mathrm{F}$ table 3.09 simultaneously. Partially intrinsic motivation of 6.464> t table 1.985 has a significant influence on employee performance, communication 4.066> t table 1.985 has a significant influence on employee performance.
\end{abstract}

Keywords: Intrinsic Motivation, Communication, Employee Performance.

\section{INTRODUCTION}

PT. Trans Retail Indonesia together with TransCorporation continues to innovate in providing worldclass service standards in the Indonesian retail industry through the Carrefour, Transmart and Groserindo brands. With more than 12,000 employees, PT. Trans Retail Indonesia continues to lead change and bring dreams to life through more than 100 multiformat outlets spread throughout Indonesia. The hybrid business concept that was first developed in Indonesia is a manifestation of innovation and transformation to strengthen Trans RetaiI Indonesia's commitment in providing world-class services and the best for Indonesian families.

The phenomenon that occurs in Transmart Ngagel is the problem of decreasing the performance of cashier employees based on initial observations and interviews. In Transmart Ngagel with a population of 98 cashier employees, employee problems are suspected to be caused by intrinsic motivation and communication. According to (Sadirman, 2007) intrinsic motivation is "motives that become active or functioning do not need to be stimulated from the outside, because in each individuals have an incentive to do something. Here, it can be seen in the initial observation that there are still many empty boxes scattered in the cashier area, the boxes are not arranged in the proper place, empty cardboard boxes here are used as an alternative to shopping bags when customers buy products in large quantities. According to (Ardana 2012) states that communication is the key to opening up the Occurrence of cooperative relationships between leaders and employees and between employees themselves. Good communication will provide a good understanding of work which has implications for employee performance which tends to increase. Some constraints that occur in the signal due to communication that has not been effective among employees with supervisors. General breeing scheduled every week goes sometimes forgotten to be realized, while this breeding is so important because there are many points discussed such as how to serve customer complaints, how to understand every promo that is available. This problem can be seen in the last 3 months report data, that there are no shortages below Rp.50,000 / month, February Rp.139,268, January Rp.94,235 and December Rp.412,255. With the existence of these two variables researchers want to know the effect on employee performance.

Based on the explanation above, this problem is considered interesting to be raised and studied more deeply. The following research questions are empirically investigated in this study

1. Is Intrinsic Motivation partially significant effect on improving Transmart Ngagel Surabaya Employee Performance? 2. Does Communication have a partially significant effect on improving Transmart Ngagel Surabaya Employee Performance?

2. Is there a significant effect simultaneously Instrinsic Motivation and Communication on improving Employee Performance in Surabaya Ngagel Transmart? 


\section{LITERATURE REVIEW}

\section{Intrinsic Motivation}

According to Singgih D. Gunarsa, (2008) intrinsic motivation is a strong drive or will that comes from within a person. The stronger the intrinsic motivation a person has, the more likely he is to show strong behavior to achieve goals. According to (Sadirman, 2007) intrinsic motivation is "motives that become active or functioning do not need to be stimulated from the outside, because in each individual there is an urge to do something

\section{Communication}

According to Gibson and Ivan (2012) suggesting " Communication is the sending of information and understanding, regarding verbal or non verbal symbols ". "Communication is the process of transferring understanding in the form of ideas or information from one person to another.

\section{Employee performance}

Rival and Sagala (2009) states that the performance is the behavior of a real show everyone as the resulting performance by employees in accordance with its role in the Organizationi

(Ermawati \& Amboningtyas, 2014) states in his journal that the Multiple Linear Regression Analysis, from the calculation of $t$ greater than $t$ table $(3.430<1.6883)$. It can be concluded that $\mathrm{H} 1$ is accepted, this shows that the intrinsic motivation variable has a positive and significant effect on the performance of employees in the production of video preparation at PT. HIT Polytron Kudus. The results of the study showed a very large influence on employee performance is intrinsic motivation. On the other hand (Rusmalinda \& Marheni, 2016) states that in his journal there is an influence between interpersonal communication on employee performance. The magnitude of the effect is $24.1 \%$ while the remaining $78.6 \%$ is influenced by other variables not examined in this study. i.e. such as organizational culture, motivation, compensation, promotion, bonuses and others

\section{RESEARCH METHOD}

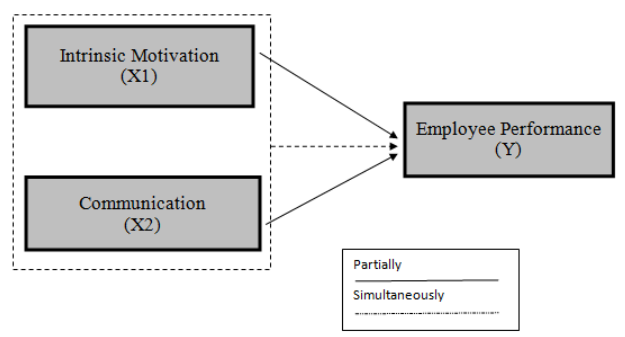

Research Hypotheses

H1: There is an influence of Intrinsic Motivation partially on the increase of Transmart Ngagel Surabaya Employee Performance

$\mathrm{H} 2$ : There is a partial effect of Communication on improving the Transmart Ngagel Surabaya Employee Performance.

H3: There is the influence of Intrinsic Motivation and Communication simultaneously on improving Transmart Ngagel Surabaya Employee Performance.

\section{The type of research}

This type of research is field research, namely direct observation of the object under study in order to obtain relevant data. This research includes quantitative research

\section{Population}

The population in this study were 98 employees of the Transmart Ngagel Surabaya cashier

\section{Types, Sources and Data Collection Techniques}

The data used in this study are primary data. Primary data is a source of research data obtained directly from the original source, namely the Ngagel Transmart Surabaya cashier. To obtain this data the researcher used a questionnaire. The questionnaire is a data collection tool in the form of a list of written questions to obtain information from a number of respondents 


\section{Multiple Regression Analysis}

This method is used to find out how much influence the independent variables (Intrinsic Motivation and Communication influence on Employee Performance dependent variables).

Multiple linear regression models are used:

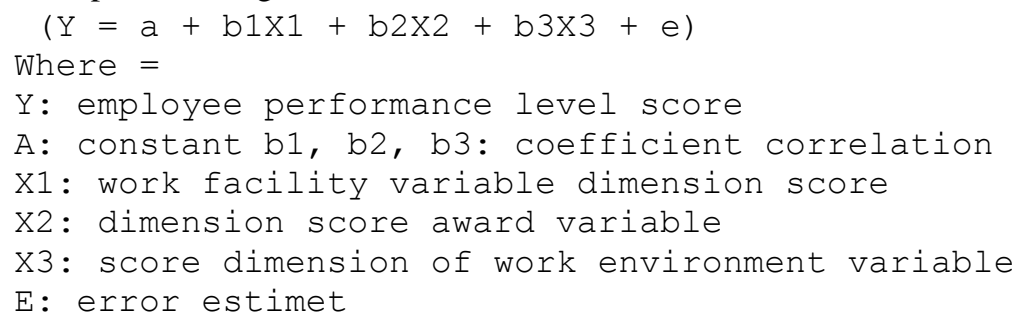

Source: Sugiono (2005)

\section{RESULTS AND DISCUSSION}

\section{Reability and Validity}

Based on research, the value of cronbanch alpha from intrinsic motivation is 0.608 , communication 0.783 , and employee performance 0.712, which means that it above the acceptance limit of 0.60 . Based on the research value of the correlation index for the relationship between independent variables (intrinsic motivation and communication) and the dependent variable (employee performance) greater than 0.202 from table $r$ and below the significant level of 0.05 , the results of the validity test of all items showed positive results, by therefore, the data is considered valid

\section{Multiple Linear Regression}

Table 1: Multiple Linear Test Results

\begin{tabular}{|c|c|c|c|c|}
\hline \multicolumn{5}{|c|}{ Model Summary $^{\mathbf{b}}$} \\
\hline Model & $\mathrm{R}$ & $\begin{array}{c}\mathrm{R} \\
\text { Square }\end{array}$ & $\begin{array}{c}\text { Adjusted } \\
\mathrm{R} \\
\text { Square }\end{array}$ & $\begin{array}{c}\text { Std. } \\
\text { Error of } \\
\text { the } \\
\text { Estimate }\end{array}$ \\
\hline 1 & $772^{\mathrm{a}}$ & 0.596 & 0.588 & 2.67018 \\
\hline
\end{tabular}

a. Predictors: (Constant), Intrinsic Motivation, Communication

b. Dependent Variable: Employee Performance

$Y=4.666+0.781 \mathrm{X} 1+0.682 \mathrm{X} 2+\mathrm{e}$ From the above equation means:

a. The constant $(\alpha)$ is 4,666 , this shows that if there is an influence of the independent variable in the form of Intrinsic Motivation variable, and Communication, then the employee' s performance will remain at 4,666

b. Intrinsic Motivation regression coefficient (b1) has a positive value of 0.781 , this means that if the Work Facility increases by one unit it will increase the performance by 0.781 units.

c. Communication regression coefficient (b2) has a positive value of 0.682 , this means that if the award increases by one unit it will increase the performance by 0.682 units

Table 2: R-Square results

\begin{tabular}{|c|c|c|c|c|}
\hline \multirow{2}{*}{\multicolumn{2}{|c|}{ Model }} & \multicolumn{2}{c|}{$\begin{array}{c}\text { Unstandardized } \\
\text { Coefficients }\end{array}$} & $\begin{array}{c}\text { Standardized } \\
\text { Coefficient }\end{array}$ \\
\cline { 3 - 5 } \multicolumn{2}{|c|}{} & B & Std. Error & Beta \\
\hline \multirow{2}{*}{1} & (Constant) & 4.666 & 3.661 & \\
& Intrinsic Motivation & 0.781 & 0.121 & 0.527 \\
& Communication & 0.682 & 0.168 & 0.332 \\
\hline
\end{tabular}


The amount of the determination coefficient ( $\mathrm{R}$ Square) is 0.596 or equal to $59.6 \%$. This number implies that the Intrinsic Motivation variable (X1) and the Communication variable (X2) simultaneously (together) affect the Employee Performance variable (Y) of 59.6\%.

\section{Results Of Classic Assumption Test}

Normality Test

Table 3: Normality Test Results Skewness Ratio and Kurtosis Ratio

\begin{tabular}{|c|c|c|c|c|c|}
\hline \multicolumn{6}{|c|}{ Descriptive Statistics } \\
\hline & $\mathbf{N}$ & Skewness & & Kurtosis & \\
\hline & Statistic & \multicolumn{2}{|c|}{$\begin{array}{c}\text { Statistic } \\
\text { Std Error }\end{array}$} & Statistic & Std. Error \\
\hline $\begin{array}{c}\text { Unstandardize } \\
\text { dbResidual } \\
\text { Valid N } \\
\text { (listwise) }\end{array}$ & $\begin{array}{l}97 \\
97\end{array}$ & -0.234 & 0.245 & -0.443 & 0.485 \\
\hline
\end{tabular}

table shows that Skewness Ratio $-0.234 / 0.245=-0.9955$ and Kurtosis Ratio $-0.443 / 0.485=-0.913$. Because the Skewness Ratio and the Kurtosiss Ratio are between -2 to +2 , it can be concluded that the normal data distribution

\section{Multicolininerity Test}

Table 4: Multicolinerity Test Results

\begin{tabular}{|ll|c|c|}
\hline \multicolumn{3}{|c|}{ Coefficient $^{2}$} \\
\hline \multirow{2}{*}{\multicolumn{2}{|c|}{ Model }} & \multicolumn{2}{|c|}{ Collinearity Statistics } \\
\cline { 2 - 4 } & Tolerance & VIF \\
\hline 1 & (Constant) & & \\
& Instrinsic Motivation & 0.645 & 1.549 \\
& Communication & 0.645 & 1.549 \\
\hline
\end{tabular}

Based on the table above, it can be explained that the questionnaire research data used can be used for further testing due to the results of this multicollinearity test, the research data has a VIF value of $<10$ and tolerance value is less than 1 .

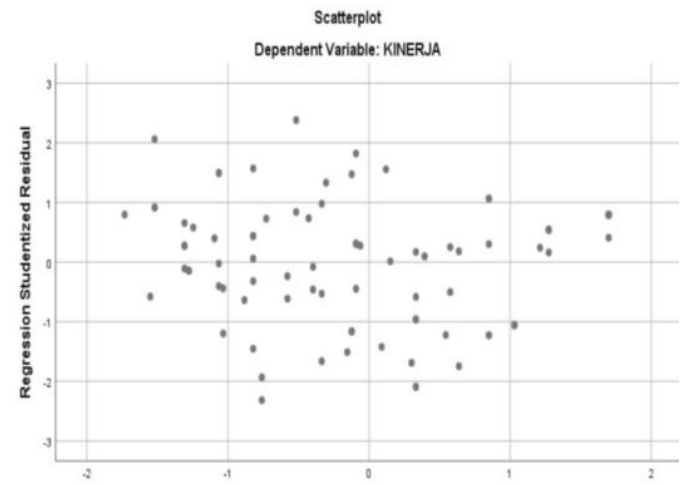

Figure 1: Scatter Plot

\section{Heterocedasticity Test (Scatterplot and Glejser Test)}

From the above output it can be seen that the points do not form clear patterns, and points -spots spread above and below the number 0 on the $\mathrm{Y}$ axis. So it can be concluded that there is no problem of heteroscedasticity in the regression model. 
Table 5: Glejser Test

\begin{tabular}{|c|c|c|c|c|c|c|}
\hline \multicolumn{7}{|c|}{ Coefficient ${ }^{\mathrm{a}}$} \\
\hline & \multirow{2}{*}{ Model } & \multicolumn{2}{|c|}{$\begin{array}{c}\text { Unstandardized } \\
\text { Coefficient }\end{array}$} & \multirow{2}{*}{$\begin{array}{c}\begin{array}{c}\text { Standardized } \\
\text { Coefficient }\end{array} \\
\text { Beta }\end{array}$} & \multirow{2}{*}{$\mathbf{T}$} & \multirow{2}{*}{ Sig. } \\
\hline & & B & $\begin{array}{c}\text { Std } \\
\text { Error }\end{array}$ & & & \\
\hline \multirow{3}{*}{1} & (Constant) & 1.455 & 2.056 & & 0.708 & 0.481 \\
\hline & $\begin{array}{l}\text { Intrinsic } \\
\text { Motivation }\end{array}$ & 0.091 & 0.068 & 0.171 & 1.345 & 0.182 \\
\hline & Communication & -0.124 & 0.094 & -0.167 & -1.314 & 0.192 \\
\hline
\end{tabular}

a. Dependent Variable: absresid

Based on the table above, it is known that the significance value (Sig.) For the Intrinsic Motivation variable (X1) is 0.182. Meanwhile, the significance value (Sig.) For the Communication variable (X2) is 0.192. Because the significance values of the two variables above are greater than 0.05 , according to the basis of decision making in the glejser test, it can be concluded that there are no symptoms of heteroscedasticity in the regression model.

\section{Results Of Testing Hypothesis \\ Test F}

Table 6 : TEST F

\begin{tabular}{|c|c|c|c|c|c|c|}
\hline & \multicolumn{6}{|c|}{ ANOVA $^{a}$} \\
\hline & Model & $\begin{array}{c}\text { Sum of } \\
\text { Squares }\end{array}$ & df & $\begin{array}{c}\text { Mean } \\
\text { Square }\end{array}$ & $\mathbf{F}$ & Sig. \\
\hline \multirow{3}{*}{1} & Regression & 990.021 & 2 & 495.010 & 69.428 & $.000^{\mathrm{b}}$ \\
\hline & Residual & 670.206 & 94 & 7.130 & & \\
\hline & Total & 1660.227 & 96 & & & \\
\hline
\end{tabular}

a. Dependent Variable: Employee Performance

b. Predictors: (Constant), Communication, Intrinsic Motivation

Based on the table above, the value of Sig. is 0,000 . Because the value of Sig. $0,000<0,05$, then according to the basis of decision making in the F test it can be concluded that the hypothesis is accepted or in other words Intrinsic Motivation (X1) and Communication (X2) simultaneously influence Employee Performance (Y). It is known that the calculated $\mathrm{F}$ value is 69,428 . Because the value of $\mathrm{F}$ count $69,428>\mathrm{F}$ table 3.09, then as the basis for decision making in the $\mathrm{F}$ test can be concluded that the hypothesis is accepted or in other words Intrinsic Motivation (X1) and Communication (X2) simultaneously influence Employee Performance (Y).

\section{TEST T}

Table 7 : TEST T

\begin{tabular}{|c|c|c|c|c|c|}
\hline \multicolumn{7}{|c|}{ Coefficient $^{\mathrm{a}}$} \\
\hline \multirow{3}{*}{ Model } & \multicolumn{2}{|c|}{$\begin{array}{c}\text { Unstandardized } \\
\text { Coefficient }\end{array}$} & $\begin{array}{c}\text { Standardized } \\
\text { Coefficient }\end{array}$ & \multirow{2}{*}{$\mathrm{T}$} & \multirow{2}{*}{ Sig. } \\
\cline { 2 - 5 } & B & $\begin{array}{c}\text { Std } \\
\text { Error }\end{array}$ & Beta & & \\
\hline \multirow{2}{*}{$1 \quad$\begin{tabular}{c} 
(Constant) \\
\cline { 3 - 5 }
\end{tabular}} & 4.666 & 3.661 & & 1.275 & 0.206 \\
\hline $\begin{array}{c}\text { Intrinsic } \\
\text { Motivation }\end{array}$ & 0.781 & 0.121 & 0.527 & 6.464 & 0.000 \\
\hline
\end{tabular}




\begin{tabular}{|l|l|l|l|l|l|}
\hline Communication & 0.682 & 0.168 & 0.332 & 4.066 & 0.000 \\
\hline
\end{tabular}

a. Dependent Variable: Employee Performance

Based on the table above it is known that the significance value (Sig) of the Intrinsic Motivation variable (X1) is 0,000 . Because the value of Sig. 0,000 <probability of 0.05 , it can be concluded that $\mathrm{H} 1$ or the first hypothesis is accepted. This means that there is an effect of Motivation (X1) on Achievement (Y). Based on the SPSS output above, it is known that the calculated $t$ value of the motivation variable is 6.464. Because the value of $\mathrm{t}$ count is $6.464>\mathrm{t}$ table 1.985 , it can be concluded that $\mathrm{H} 1$ or the first hypothesis is accepted. This means that there is the influence of Intrinsic Motivation (X1) on Employee Performance (Y). It is known that the significance value ( $\mathrm{Sig}$ ) of Communication variable (X2) is 0,000. Because the value of Sig. 0,000 <probability 0,05 , it can be concluded that $\mathrm{H} 2$ or the second hypothesis is accepted. This means that there is the influence of Communication (X2) on Employee Performance (Y). Based on the SPSS output above, it is known that the calculated $t$ value of the motivation variable is 4.066. Because the value of $t$ count is 4.066>t table 1.9855, it can be concluded that $\mathrm{H} 2$ or the second hypothesis is accepted. This means that there is the influence of Communication (X2) on Employee Performance (Y).

\section{DISCUSSION}

1. The Influence of Intrinsic Motivation on Employee Performance

Based on the results of the study showed that the value of $t$ count $6.464>t$ table 1.985 and the significance level of $0.000<0.05$, then $\mathrm{H} 1$ is accepted and H0 is rejected, meaning the Intinsic Motivation variable (X1) has a positive and significant effect on employee performance (Y).

In this case, motivation can be used as the main criterion for determining employee performance in the organization.

2. The Effect of Communication on Employee Performance

Based on the results of the study showed that the value of $t$ count 4.066>t table 1.9855 and the significance level of $0.005<0.05$, then $\mathrm{H} 2$ is accepted and $\mathrm{H} 0$ is rejected, meaning the Communication variable (X2) has a positive and significant effect on employee performance ( Y). In this case, Communication can be used as the main criterion for determining employee performance in the organization.

3. Effects of Intrinsic Motivation and Communication on Employee Performance

Based on the results of the study, the Intrinsic Motivation and Communication variables have a positive and significant effect on employee performance variables, because 69,428> F table 3.09 and a significant level of $0,000<0.05, \mathrm{H} 1$ is accepted and $\mathrm{H} 0$ is rejected with the meaning that the Intrinsic Motivation and Communication variables have a positive and significant effect on employee performance variables.

\section{CONCLUSION AND SUGGESTIONS}

\section{CONCLUSION}

Based on the results and research and discussion that has been described, namely:

1. There is a positive and significant influence between intrinsic motivation on the performance of the employees of the Ngagel Transmart Surabaya cashier, which is indicated by the value of $\mathrm{t}$ count $6.464>\mathrm{t}$ table 1.985 , significance level $0.000<0.05$. It means that if Intrinsic Motivation increases, it will improve employee performance.

2. There is a positive and significant influence between Communication on the performance of the employees of the Ngagel Transmart Surabaya cashier, which is indicated by $t$ count 4.066 $>\mathrm{t}$ table 1,985 and the significance level of $0.005<0.05$. Means if communication increases it will improve employee performance.

3. There is a positive and significant influence between intrinsic motivation and communication performance of the employees of the Ngagel Transmart Surabaya cashier, which is indicated by the calculated $\mathrm{F}$ value of 69,428 at the $5 \%$ significance level ( $\mathrm{F}$ count $>\mathrm{F}$ table) that is due to $69,428>\mathrm{F}$ table 3.09. This means that Intrinsic Motivation and Communication are increasing together so it will improve the performance of employee 


\section{SUGGESTIONS}

\section{For Companies}

a. Management needs to explain the importance of intrinsic motivation, where motivation is needed to achieve the expected performance results and are needed for the employee itself to improve his skills in work, both individually and in groups

b. The supervisors should continue to guide and support the efforts made by the employees, so that they feel the results of their work are valued, where this sense of respect will increase their job satisfaction and motivation in the future.

c. Companies should increasingly improve communication between employees, employees and superiors so that performance increases by making efforts such as formal meetings such as meetings between employees, between superiors or employees with superiors.

d. A boss pays more attention to communication that will be conveyed through gesture, so that employees can understand

\section{For Employees}

a. It is better to pay attention to things that can improve performance to improve the performance system better, so that it can provide value the best value for Transmart Ngagel Surabaya

b. Employees pay more attention to the challenges given by the company by accepting and running according to the existing process

c. Employees pay more attention to the timeliness in completing all tasks given by the company

\section{For Researchers}

For further research you should add other variables that can affect employee performance such as Compensation, Extrinsic Motivation and Leadership so that it can be compared in research.

\section{REFERENCES}

A.A Anwar Prabu Mangkunegara. (2012). Manajemen Sumber Daya Manusia. Bandung: PT. Remaja Rosdakarya.

Ardana, \& Komang, I. (2012). Manajemen Sumber Daya Manusia. Yogyakarta: Graha Ilmu.

Ardiansyah, D. O. (2016). Pengaruh Komunikasi Terhadap Kinerja Karyawan Dengan Dimediasi Oleh Kepuasan Ker/Ja. Jurnal Bisnis Dan Manajemen, VOL.3 No.1(4), 16-30. https://doi.org/10.13140/RG.2.1.5183.7283

Atambo, W., \& Momanyi, D. (2016). Effects of Internal Communication on Employee Performance: A Case Study of Kenya Power and Lighting Company, South Nyanza Region, Kenya. Imperial Journal of Interdisciplinary Research (IJIR), 2(5), 328-340. https://doi.org/10.1103/PhysRevLett.72.2125

Dirianzani, L., Sugiono, \& Hardiningtyas, D. (2014). Sebagai Mediasi ( Studi Kasus : Perusahaan Rokok Adi Bungsu Malang ) Analysis of The Effect of Intrinsics and Extrinsic Motivation on Job Performance of Contract Employees with Organizational Commitment as Mediation ( Study of Perusahaan Rokok Adi Bungsu M. Jurmal Rekayasa Dan Manajemen Sistem Industri, 2(5), 1124-1135.

Elida Prayitno. (1989). Motivasi Dalam Belajar dan Berprestasi. Jakarta.

Ermawati, \& Amboningtyas. (2014). Pengaruh Motivasi Intrinsik, Komunikasi,Dan Kompensasi Finansial Terhadap Kinerja Karyawan Produksi Video Preparation Pada Pt Hit Polytron Yang Berimplikasi Pada Produktivitas. 63(9), 1-7. https://doi.org/10.7498/aps.63.094206

Femi, A. F. (2014). The Impact of Communication on Workers' Performance in Selected Organisations in Lagos State, Nigeria. IOSR Journal of Humanities and Social Science, 19(8), 75-82. https://doi.org/10.9790/0837-19827582

Handoko. (2011). Manajemen Personalia Sumberdaya Manusia. Yogyakarta: BPFE.

HMathis, \& Jackson. (2009). Manajemen Sumber Daya Manusia (10th ed.). Jakarta: Salemba Empat.

Nisa, I., Rooswidjajani, \& Fristin, Y. (2018). Pengaruh Komunikasi dan Lingkungan Kerja Fisik Terhadap Kinerja Karyawan, Indah Choirun Nisa, Rooswidjajani, Yuntawati Fristin. 5(2), 198-203.

Nurun, N. dkk. (2017). The Role and Impact of Business Communication on Employee Performances and Job Satisfactions: A Case Study on Karmasangsthan Bank Limited, Bangladesh. 7(1), 1-8. https://doi.org/10.4172/2223-5833.1000301

Nwata, Phipip, U., \& Amah, E. (2016). Internal Organizational Communication and Employees 'Performance in Selected Banks in Port Harcourt. International Journal of Novel Research in Humanity and Social Sciences ISSN 2394-9694, 3(3), 86-95. 
Pamela Akinyi, A. (2015). Effect of motivation on employee performance of commercial banks in Kenya: A case study of Kenya Commercial Bank in Migori County. International Journal of Human Resource Studies, 5(2), 87-103. https://doi.org/10.1108/02652320210451223

Rusmalinda, S., \& Marheni, S. (2016). Pengaruh Komunikasi Interpersonal Terhadap Kinerja Karyawan Di Lembaga Bimbingan Dan Konsultasi Belajar Prestise. E-Proceeding of Management, 3(1), 492-496.

Sadirman. (2007). Interaksi dan Motivasi Belajar Mengajar. Bandung: Rajawali Pers. 